CESIS Electronic Working Paper Series

Paper No. 428

\title{
Embracing the sharks: \\ The impact of information exposure on the likelihood and quality of CVC investments
}

\author{
Ali Mohammadi \\ Pooyan Khashabi
}

March, 2016 


\title{
EMBRACING THE SHARKS: \\ THE IMPACT OF INFORMATION EXPOSURE ON THE LIKELIHOOD AND QUALITY OF CVC INVESTMENTS
}

\section{Ali Mohammadi ${ }^{1}$ \& Pooyan Khashabi ${ }^{2}$}

\begin{abstract}
For high-tech startups, gaining access to resources and funding is often considered crucial. This need has created technology markets to attract partners and resource providers. Corporate venturing is a form of markets for technology (MfT) that provides nurturing, specialized advice and resources to new technology by investing in startups. However the typical issues involved with MfT - namely misappropriation risks- have made startups reluctant about sharing their key technological information with corporate venture capitalists (CVC), potentially retarding efficient market matching and consequently technology development. Lifting informational constraints may facilitate the market and enable us to measure the pure impact of CVC investment. Assessing the potential impact of information constraints has been challenging due to severe endogeneity concerns. This study investigates the causal impact of technological information exposure on the likelihood, quality and timing of CVC-startup match formation. We exploit the American Inventor's Protection Act (AIPA) as an exogenous shock to technological information publicity, which enables us to measure an unbiased impact of information exposure. The results confirm that strategic information withhold by startups has lowered the incident of CVC investments, while informational exposure increases the likelihood, quality and hazard rate of CVC-startup match.
\end{abstract}

Keywords: American Inventor's Protection Act, Corporate Venture Capital, Information revealing, high-tech startups, Misappropriation

JEL Classification: G14, L26, M13, O32

Acknowledgement: We owe thanks to Massimo Colombo, Alfonso Gambardella, Tobias Kretschmer, Claudio Panico, Koroush Shafi, and Karl Wennberg for helpful comments and discussions. All remaining errors are our own.

\footnotetext{
${ }^{1}$ Centre of Excellence in Science \& Innovation Studies (CESIS), Department of Industrial Economics and Management, Royal Institute of Technology (KTH), 10044 Stockholm, Sweden. Phone: +46 87907253. E-mail: ali.mohammadi@indek.kth.se

${ }^{2}$ Ludwig-Maximilians-Universität (LMU), Munich School of Management, Institute for Strategy, Technology and Organization, Kaulbachstr, 45, 80539 Munich, Germany. Phone: +49 8921805415.

E-mail: p.khashabi@1mu.de
} 


\section{INTRODUCTION}

The role of external financing in nurturing and diffusion of technology and innovation has been found crucial (Kortum and Lerner, 2000). Thus, high-tech startups need to disclose their key technological information in a market to potential investors in order to attract resources. This creates a market for technology (MfT) from the investors' side to detect and evaluate technologies of startups and decide whether or not to invest on them. Typically, this role is carried out by venture capitals (VCs) and corporate venture capitals (CVCs) in the high-tech areas. The role of these investors on the development of technology and supporting the startups is not limited to the provision of financial resources. VCs and CVCs not only provide capital, but are also providers of specialized advice, human resources, technological capital and monitoring (see e.g. Gompers and Lerner, 2004; Hellmann and Puri, 2002; Hsu, 2006). Thus, one could imagine that a matching between technology startups and these investors can create value for both sides, besides social welfare gain through technology development and diffusion. Moreover, the extent of value creation would be higher when the quality of match is better (i.e. when the quality of startups and the volume of funding is higher) or when the matching happens faster (i.e. when the startup reaches the funding after shorter evaluation time by investor).

Despite the above, issues such as asymmetric information, search costs and misappropriation risk are common companions in any form of MfT (Arora, Fosfuri and Gambardella, 2001; Arrow, 1962; Gans and Stern, 2010), and corporate venturing is not an exception. Technology holders may limit information disclosure in order to avoid misappropriation by potential partners (Arrow, 1962; Anton and Yao, 1994), particularly when the other party is more likely to misappropriate the information. Moreover, matching in the market for technology require a costly and time consuming search process (Gans et al., 2008), limiting technology partnerships (Hellmann, 2005).The startup-investor matching 
process is not free of tension, which may reduce the likelihood and quality of the match. It is a well-established issue in organization and strategy research that firms are pushed away from inter-organization relations due concerns on potential misappropriation of their resources by their partners (Ahuja, 2000; Gulati and Singh, 1998; Katila and Mang, 2003). As a result, startups may strategically hide their key technological information when collaborating with investors, to protect themselves against the risk of misappropriation by the investor (Dushnitsky and Lenox, 2006). This issue would cause information asymmetry -hidden information- between the investor and technology startup that is known to be a big hassle in venture financing (see e.g. Gompers, 1995). These information constraints, create congestions in MfT (Gans and Stern, 2010) and could retard timely and efficient matching, resulting in lower technological development and innovation.

The issue of strategic information withhold discussed above is significantly relevant for the case of CVC-startup matching. Unlike independent VCs that have the mission to finance and support a startup purely to maximize its returns (Gompers and Lerner, 2004), CVCs have dual objectives. Besides sharing the mission of maximizing the startups' return, they invest to gain a window to new technology (Benson and Ziedonis, 2009; Dushnitsky and Lenox, 2006). This strategic objective of CVCs are even claimed to be more important for them compared to startups' financial return (Alter and Bachsbaum, 2000, Siegel and MacMillan, 1988; Yost and Devlin, 1993). An objective that is not shared by independent VCs. The strategic objectives to gain information from startups about new technological bets have made startups to be reluctant to i) collaborate with CVCs - especially when they are active in similar technological fields (see e.g. Dushnitsky and Shaver, 2009) and ii) hide their key technological information due to misappropriation risk. An issue which is known in the literature as "swimming with sharks" concern (Katila, Rosenberger, and Eisenhardt, 2008). However, this behavior may have caused large value creation and welfare losses. Researchers have documented that CVC 
investments create high values (Dushnitsky and Lenox, 2005a, b) and are important sources of financing for the development of innovative technology of startups (Alvarez-Garrido and Dushnitsky, 2015; Chemmanur, Loutskina, and Tian, 2014). Moreover, due to their industry experience, ownership of advanced complementary resources and expert human capital, CVCs are likely to create higher value for startups compared to independent VCs (Gompers and Lerner, 1998). Thus, CVCs may be the optimal suppliers in MfT for startups and matching with them may increase the likelihood of success for both startup and CVC (Dushnitsky and Lenox, 2006). However, sever information constraints in CVC financing creates a big loss in MfT and depresses the advantages of CVC investments. However, the positive claims above on CVCs have not been assessed precisely, since the counterfactual i.e. a MfT with less information constraints for CVCs- is very difficult to conceive. Thus, understanding how information asymmetry impacts the corporate venture financing activity is pivotal to assess the positive role of CVCs in MfT. However, measuring such an effect is a big empirical challenge. To have a robust analysis, one should study the causal impact of information asymmetry -or disclosure- on the match likelihood and quality. Such a practice would be very much prone to endogenity concerns arising from various unobserved heterogeneity and omitted variable biases; an issue which dominates the majority of empirical literature on this topic. This study, is an effort to measure the unbiased causal impact of information asymmetries on the likelihood and quality of CVC-startup matching, thanks to an exogenous change in US patent law in 1999. The American Inventor's Protection Act (AIPA) as an exogenous shock, provides an exceptional and unique opportunity to answer to the above questions, without endogeneity concerns. As a result of AIPA, high technology startups experienced a change in the publicity of their technological information, which reduced the information asymmetry significantly (Graham and Hegde, 2015). The shock hit the industries were the link between intellectual property and value appropriation was 
transparent. As a result, in these industries, startups lost their information advantage over CVCs. Our theoretical arguments discuss how the shock would impact the likelihood and the quality of the match in such industries. We theorize that as a result of this shock, CVCs face less risky investments (market of lemons syndrome). And from the startup's side, the tradeoff between receiving finance versus risk of misappropriation becomes much less relevant- since the information is already revealed. Thus we expect that the likelihood of CVC-startup matching increases -compared to VC-startup matches- and conditional to that, the quality of matches improve after the shock. Furthermore, with lower informational constraints for the CVC and misappropriation concern for the startup, we expect the match process become smoother resulting in a faster match formation.

To test our theory, we construct a sample of 38,286 rounds of investment in 14,418 high-tech entrepreneurial ventures. We appreciate that endogeniety may potentially be an issue; hence by exploiting the exogenous shock (AIPA) we use difference-in-difference methodology using the industries hit by the shock as our treatment group. The results confirm our theoretical argument that informational revealing increase likelihood and quality of CVCstartup matching compared to independent VC-startup matches. Moreover, CVC-startup matching happens significantly faster with respect to VC matches after the shock. In order to allay concerns about robustness of our results, we use an extensive list of controls, alternative measures of dependent variables, subsampling and a placebo test.

This study contributes to the related literature in several ways. First, we consider a special form of MfT (CVC) to discuss the conditions that facilitate emergence of a wellfunctioning market in our context. Second, by making use of an exogenous shock, our study assesses the theoretical arguments in prior literature on the positive advantages of CVC investments, in the absence of informational constraints. Third, by explaining a key factorinformation revealing- in the likelihood, quality and timing of venture financing, we explain a 
part of substantial variation in the performance of CVCs; an issue which scholars have been studying to understand its cyclical nature (Dushnitsky and Lenox, 2006). And finally, by providing a robust analysis on the impact of an IP policy change, we provide policy implications for improving the development and diffusion of innovation in uncertain environments.

The remainder of the paper is organized as following. The next section discusses the information asymmetry within entrepreneurial finance literature, AIPA and develops our hypotheses. Thereafter we present the data, variables, and regression evidence. Finally, we discuss our findings and the limitations of this research and conclusion.

\section{BACKGROUND}

\section{Information Asymmetries}

Information asymmetries are among the most important factors impacting MfT (Arora et al., 2001) and venture investment process. These asymmetries can be in the form of hidden action (when the investing partner cannot perfectly monitor the startups operations) or hidden information (when the startup holds valuable information that the investor lacks) (see e.g. Gompers, 1995: Kaplan and Sromberg, 2004). In our study, we focus on the latter case, which leads to adverse selection concern. Such concerns exist since the investors -in our case VCs or CVCs- do not completely observe the characteristics of the startup. These characteristics typically include information on the entrepreneurial idea -e.g. the real value of idea, the technological details, processes and etc. In the case of high-tech startups, the key component would be the technological details which would typically reflected in their IP (Baum and Silverman, 2004; Hsu and Ziedonis, 2013; Mann and Sager, 2007).

Since the demand for external funding typically exists in the early start-up stage (where there is almost no record and signal available to the investor), hidden information becomes a 
very pronounced issue. Although venture investors have developed tools - such as staging - to mitigate the substantial information asymmetry issues (see e.g. Ueda, 2004), yet, there would still remain a big chunk of valuable private information by the startup that are not accessed by the investors (Gans and Stern, 2003). A factor that causes serious concerns on the profitability of investments in ventures (Dusnitsky and Lenox, 2006) due to selection of low quality startups.

A part of this information asymmetry is due to the intention of low quality startups trying to sell themselves as high quality (a nut instead of a lemon), however, a big part of it also comes from another strategic withhold of information by ventures. As the literature highlights, ventures are more likely to hide their valuable technological information from the investor for the risk of expropriation, especially when the IP regime is weak (Dushnitsky and Lenox, 2006; Dushnitsky and Shaver, 2009) or when the investing partner is more likely to misappropriate the rents (Dushnitsky and Lenox, 2006; Dushnitsky and Shaver, 2009; Katila et al., 2008). This issue is more relevant for the case of CVC investments, which generates rampant information asymmetry in their case. We discuss this issue in further details below.

\section{Misappropriation Risk and Strategic Information Withhold}

As discussed, startups with lower technological value would typically try to withhold information on their key technology, as a way to be considered as a high value venture and increase their chance of receiving funding (Cumming, 2006). This is the baseline level of information asymmetry in our analysis. However, the information issue becomes much more complicated when interacted with the strategic objectives of venture investors. When the startup is concerned that its key technological -and entrepreneurial- information is under the risk of expropriation, it may strategically hide information as a self-protection mechanism (Dushnitsky and Lenox, 2006; Dushnitsky and Shaver, 2009; Katila et al., 2008). This actually creates another dimension, on the top of the baseline information asymmetry between 
the startup and the investor, for misappropriation concerns. Notice that the main difference between these dimensions of information asymmetry with the baseline is on the intention of the startup to withhold information. This dimension is more subtle than the baseline asymmetry, since its extent would largely depend on the objectives of the investor, and consequently on the risks associated with the information disclosure of startup (Dushnitsky and Lenox, 2006; Dushnitsky and Shaver, 2009).

This is actually the case with CVC firms' investments. Unlike Independent VCs, CVCs have other strategic objectives in their venture investments, besides financial return and startup success (Benson and Ziedonis, 2009; Dushnitsky and Lenox, 2005b). It is well established in the literature that CVCs use venture investments as a window to new technology (Benson and Ziedonis, 2009; Dushnitsky and Lenox, 2005b; Dushnitsky and Lenox, 2006). Also surveys have revealed that this even ranks as the primary objective of the CVCs in venture financing (Alter and Buchsbaum 2000; Siegel, Siegel et al.,1988; Yost and Devlin 1993). Moreover, research has shown that CVCs actually in some cases, have misappropriated the technology of their financed startups (Katila, et al., 2008), especially where the intellectual property regime was weak (Cohen, Nelson and Walsh, 2001), or that when they had the right complementary assets for that technological field (Dushnitsky and Shaver, 2009). The threat in the literature is referred to as the misappropriation risk, or “swimming with sharks" phenomena (Katila, et al., 2008).

An important point about the misappropriation risk is that it is not associated with independent venture capitals. Accordingly, it is natural to expect that startups would be much less concerned of coordinating and revealing their key technological information to VCs, compared to CVCs. Thus, the startups would be reluctant to i) start a collaboration with CVCs and ii) if started, reluctant to disclose detailed technological information to them. As a result, this mechanism would have two distinct impacts on CVC-startup matching. Firstly, this 
would reduce the likelihood of startup-CVC matching: since accepting an investment from CVCs comes with the high risk of misappropriation for the startups, the tradeoff would cause many high quality startups not having the external resources due to misappropriation concerns. Secondly, even if a CVC-startup match occurs, the misappropriation risk would reduce the match quality -due to strategic information withhold from the startup- and eventually lower the return of CVC-backed ventures.

On the impact of misappropriation on the likelihood of investment matching, few empirical studies have found evidence that startups refrain to collaborate with CVCs, when the risk of misappropriation is high. For example, Dushnitsky and Shaver (2009) find that there are less number of CVC-startup matches when the technological field of startup, overlaps with the one of CVC. On the second impact -i.e. the deterring impact on the match there has not been much empirical evidence. As some scholars believe that CVCs would be much more effective than independent VCs for the profitability of startups, since they provide more specialized human capital, technical advice and monitoring (Gompers and Lerner, 1998; Maula and Murray, 2002). However, the rampant information asymmetry creates serious skepticism on the efficiency of these investments compared to CVC investments (Dushnitsky and Lenox, 2006). Since there are various factors impacting the quality of investment collaborations, the empirical studies measuring the effect of misappropriation threat would be prone to omitted variable bias concerns. An issue that we claim to be immune to, thanks to the exceptional opportunity generated by the exogenous shock in the US patent law, which we will explain in the next section. 


\section{INFORMATION ASYMMETRY REDUCTION AND VENTURE INVESTMENTS}

\section{American Inventor's Protection Act (AIPA)}

Before 1999, there was an in important feature in the US patent system that made it quite exceptional compared to the rest of the world. Unlike other major patent systems (e.g. Europe or Japan), patent application details were publicly disclosed, only after the patent was granted (Gallini, 2002). In theory, this could have last up to 20 years (Graham and Hegde, 2015). Thus, high-tech startups could hide their key technological information without losing their IP protection. A practice which was known as "submarine patenting". Submarine patenting could give high-tech startups the control to choose how, when and to which investor they want to share the information. In 1999, a new patent law -known as the American Inventor's Protection Act (AIPA) - was passed by Congress, which required all the patent applications filed in the US and abroad to be laid open for public inspection, 18 months after the initial filing date. This act harmonized the US patent law with the rest of the world and disclosed the patent information, even if the patent was not granted. This change was described as IP protection weakening shock by scholars (see e.g. Gallini, 2002) that hit the majority of patent applications. This is because it is extremely unlikely that a patent application in USPTO leads to a grant in less than 18 months. According to the USPTO figures, just the first office action for a patent application will take more than 17 months on average, and each patent would go through an average of 2.5 office actions for the final decision (USPTO Online Data Dashboard, 2015). Also, if an invention in a crowded art - as it is the case for most high-tech startups such as computer software entrepreneurs- the waiting time could double. And finally, these figures do not take into account the possibility that USPTO makes a Request for Continuing Examination (RCE) which can make the process even longer. Therefore, almost any patent application made after 1999, was revealed to public as a result of AIPA. Also since most of the high-tech startups are shaped around a patent 
(Baum and Silverman, 2004; Hsu Ziedonis, 2013; Mann and Sager, 2007), the shock significantly impacted startups in high tech sectors. As a direct result of AIPA, there was a sharp reduction on the information advantage of startups over venture investors. After AIPA, high-tech startups, typically having patents as their main asset, lost the control over a big chunk of their technological information, which were not IP protected.

Despite the above, the information disclosure benefits of AIPA is not uniformly significant for CVCs across different industries. This difference is related to the distinct relation of patents and rent appropriation across industries. Although patents go through a standard legal process, however the ability of patent to generate rents differs substantially, dependent on the patent's technological field. As Heeley, Matusik and Jain (2007) discuss, in some industries, the link between a patent and rent generation is "transparent". In such industries -e.g. Biotech- patents are financially significant, because the process of generating rent through them is transparent thorough patent information, and so, patent filing happens primarily for value appropriation motives. On the contrary, there is another category of industries where typically contain large number of patents, yet not significant for rent generation (Cohen et al., 2000). In these industries, there is not such a transparent link between a patent and rent appropriation, and patent filing is generally due to other motives. In line with the previous studies, we expect that AIPA's impact to be relevant on the first category of industries (hereafter transparent industries), since patent information in these industries is relevant for rent appropriation and could be misappropriated by CVCs. For the patents outside transparent industries, we do not expect AIPA to have a significant information impact, since disclosure of information in those industries would not be of an interest for CVCs.

The distinct effect of AIPA on transparent vs. non-transparent industries -as discussed above- serves as the basis for our diff-in-diff analysis to measure the causal effect of 
information disclosure on the likelihood and quality of investment matches between CVC and startup.

The overall effect of AIPA has been disputed among scholars. The new act in the first place was designed to create a more stable environment for developing new technology, since it tend to reduce the probability of a firm inadvertently working on an invention that infringes part of another pending patent (Gallini, 2002). However, some scholars predicted a disclosure shock such as AIPA to reduce the number of applications, while raising the probability of the commercialization of the remaining patent applications (Aoki and Spiegel, 1998). Our framework provides a robust analysis for examining the welfare effect of AIPA through the venture investment point of view.

\section{Theoretical Implications}

As discussed, AIPA exogenously changed information publicity for transparent industries, which would affect the startup-investor matching process in these areas. Analyzing this impact on the venture financing outcomes would create a unique opportunity to test the theoretical arguments in the literature and provide valuable policy advice for the future. Below, we discuss the impacts of AIPA through relevant mechanisms and provide testable implications for our empirical analysis.

\section{Likelihood of Matching}

To discuss the impact of AIPA on the magnitude of investor-startup matches, we decompose the effect to the funding supply (investor) and demand (startup) sides. Our focus in this section will be transparent industries, clearly because the effect of AIPA was significant inside them. The non-transparent industries will serve as a control group in our analysis to enable a causal inference. 
We start with the supply side and differentiate between two types of funding suppliers: VC and CVC. As mentioned before, the investors in general suffer from hidden information from the startup side. The baseline information asymmetry is uniformly hitting VCs and CVCs. AIPA significantly reduces the baseline information asymmetry in the favor of investors in transparent industries. Obviously, when the technological details of the patent are published during the patent application, investors would access these information, which would help them to detect nuts among lemons (i.e. detect high quality startups). As a result, the adverse selection concern -which has traditionally made investors hesitant to start the funding collaborate- would reduce significantly post-AIPA. On this respect, we could expect that both VCs and CVCs would make more funding collaborations post-AIPA, due to access to superior information. However, the impact of AIPA is not limited to the reduction of baseline information asymmetry. As discussed, CVCs suffer from stronger asymmetry due to startup's strategic information withhold. Thus, some technological details that startups would disclose to VCs are typically hidden from CVCs. This is the place that we expect AIPA to make a change: as a result of this patent law change, informational gain for CVCs would be much higher than independent VCs. Thus, the information asymmetry reduces much more for them (CVCs come closer to VCs' level of information). Accordingly, we expect that after the shock, in transparent industries, CVCs have a higher jump in their incentives to supply finding, as compared to VCs. This would be associated with higher likelihood of CVC-startup matches.

The above argument analyzes the effect of AIPA on the likelihood of matches from the funding supply side. To check for the effect from the demand side, we focus on the startups point of view. The startups, after the AIPA partly lose information advantage in transparent industries. In these industries, after AIPA, startups have much less ability to hide key technological information from CVCs compared to pre-AIPA period. This puts their most 
valuable intangible assets in the risk of misappropriation, even without collaborating with CVCs. Thus, the tradeoff of receiving funding with the risk of being expropriated would no longer be relevant for them. In this situation, CVCs already have accessed to a considerable part of startup's technological information, thanks to the new disclosure regulation (i.e. AIPA). Thus, refraining from the collaboration with CVCs would no longer protect the startup's technology and future rent, as it would have done pre-AIPA. Moreover, since AIPA has clearly made the startup's information public, other non-funding corporates would also access this information - which happens to be valuable in transparent industries. Since the IP protection is not effective in concealing the information post AIPA, it would be actually more beneficial for a startup to collaborate with CVCs -rather than VCs- to protect the technology with CVCs complementary resources. A strategy which is well known in Innovation research (Arora and Ceccagnoli, 2006; Arora, Fosfuri and Gambardella, 2001). Since CVCs possess higher levels of complementary assets, matching with CVCs can lead to a faster commercialization and profits, which is a crucial for rent appropriation (Teece, 1986). Therefore, we expect that after AIPA, in transparent industries, the incentives and demand for CVC matching increase from the startup side, compared to the VC side. Since both demand and supply side mechanisms predict a positive impact on the number of CVC-startup matches, we hypothesize:

\section{H1. The likelihood of CVC-startup matching increases as a result of an informational} (technological) revealing.

\section{Quality of Matching}

The above arguments for the impact of AIPA on the magnitude of matching also would apply to the quality of matches. By quality of match in our study we refer to the quality of the funded startup -which generally translates to the amount of investment that the investor 
provides. From the investors' side, classic adverse selection issue would be mitigated when information asymmetry reduces. Therefore, in transparent industries, CVCs enjoy a better detection technology to avoid lemons in the market. Moreover, it is sensible to assume that in pre-AIPA period, higher value startups practiced strategic information withhold to CVCs more significantly than low value startups. Therefore, by reducing the trade-off of collaborating with CVCs, AIPA exposes much higher quality pool of startups to CVCs. This would also enable a higher degree of freedom in selection of startups, eventually leading to higher quality selections. Last on the funding supply side, when an investor -CVC in this case- could better observe the quality of the startup, it would assign lower risk to the investment project. This would lead to higher installments and more investment, which would eventually lead to higher returns.

On the demand side (startup), as discussed above, by reducing the outside option of collaborating with CVCs, AIPA would drive higher value startups to collaborate more closely with CVCs. Also, conditional on collaboration, since in transparent industries post-AIPA, the startup's key information is exposed to other competitors, the startup and CVC have much better aligned incentives to commercialize the investment project together - due to having common competitors. Having CVC as a closer partner, the startup would endogenize the CVCs profit from the project and contribute more to the success of the investment by sharing more information. All in all we expect that AIPA improves the quality for the CVC backed ventures.

H2. The quality of CVC-startup matches increases as a result of an informational (technological) revealing. 


\section{Timing of Matching}

Timing of a match can be of utmost importance for the success of a startup. This importance is even more significant for high-tech startups that operate in areas where the pace of technology is extremely fast and delays in receiving resources - and developing the technology- can considerably lower the technological advantage. The discussion on the timing of the CVC-startup match in this section follows the same direction of our arguments above.

As discussed, CVCs suffer from stronger asymmetry due to startup's strategic information withhold. This information withhold, causes CVCs to get into a costly search and evaluation process to detect the true value of startups. Obviously, the more sever is the information constraint, the more costly and time consuming would be the evaluation and search process by CVCs. Accordingly, we expect that after the shock, in transparent industries, CVCs enjoy a higher jump in information regarding the startups technology and therefore result in faster search and evaluation process. Since CVCs after the shock in transparent industries would detect the nuts faster and with higher certainty, from the supply side, we expect that CVCs evaluation and decision period becomes shorter and offer funding and partnership faster compared to pre-IPA period.

To check for the effect from the demand side, we focus on the startups point of view. The startups, after the AIPA would be partly exposed to most players in the industry (including other startups, VCs and CVCs). As also discussed, at this stage, commercializing and developing their technology becomes extremely important, since time and first movers' advantage serves as a key factor in defending their technology. At the same time, fast and efficient commercialization often would require collaborating with more established ventures in control of key complementary assets including technological resources, market share, distribution network, brands and etc. (Teece, 1986). Thus we expect that after AIPA, in transparent industries, startups also accept CVC partnership offers faster to protect their 
technology. This could be in the form of accepting early -and potentially less attractivepartnership offers, or spending less time on evaluating the misappropriation concerns of collaborating with a certain CVC. Thus, both demand and supply side mechanisms predict a positive impact on the timing of CVC-startup matches, we hypothesize:

\section{H3. CVC-startup matching happens faster as a result of an informational} (technological) revealing.

\section{METHODS}

\section{Data}

We use the SDC Platinum database to build the sample of VC-backed startups. We consider all VC rounds of financing in the United States (U.S.) from 1995 to 2006. SDC Platinum is the standard database that has been used extensively in studies that focus on venture financing and CVC (Gompers and Lerner, 2004; Katila et al., 2008).

We limit our study to investments that there are at least one independent VC or CVC. The data runs until the end of 2015, but we limit our observation to investments until 2006 . This allows us to track the exit events. We allow at least 9 years for exit event. We also exclude all investments in non-high tech industries. The reason for exclusion criteria is that we focus on technological information and we expect technological information to be relevant for high-tech startups. After excluding observations with missing data, we obtain 38,286 rounds of investment in 14,418 startups.

\section{Dependent Variables}

The first dependent variable (H1) is the probability that a startup receives investment from at least one $\mathrm{CVC}$ in focal round of investment (Deal CVC). In line with the previous studies, we excluded any financial institutions such as banks or insurance companies that provide equity investment for startups (Dushnitsky and Lenox, 2005b; Katila et al., 2008). 
The second dependent variable in our analysis (H2) is the amount of investment that the startup receives. This amount typically goes hand in hand with the value (quality) of the technology startup. Thus, we consider the amount of money (natural logarithm) that the startup receives in the round (Round size) of investment (inflated by millions of 2007 dollar). Although pre-money valuation would a more accurate measure of quality, this proxy is only reported for a very small sub sample, not applicable for regression analysis. Larger round size exhibits investors have given higher valuation to the startup (Cumming and Dai, 2012).

\section{Explanatory Variables}

The first dependent variables is the time dummy (Post-AIPA), taking the value of one if the investment happened after U.S enacted the AIPA (after 2000) and zero if it happened before that.

In line with our theoretical argument, we assume that effect of AIPA on information disclosure is different for different industries. We build a dummy (transparent) equal one for industries where the link between patents and innovative products is transparent (see Heeley

et al., 2007 for the same approach). We expect that informational disclosure of AIPA will affect startups in transparent industries, unlike industries with low transparency (i.e. transparent=0).Following Heeley et al. (2007) we use SDC platinum industry classification and consider "Biotechnology" and "Medical/Health/Life Science" as transparent industries (Transparent). As a robustness check, we also use a less conservative classification (Transparent1) including “Semiconductors/Other Electrics" inside transparent industries.

\section{Control Variables}

In our model we control for several variables that might affect the likelihood of receiving CVC and size of investment. Investors commit capital in different round of investments instead of making an upfront investment of all required capital. This practice is 
known as staging (Sahlman, 1990). In each round investors are able to observe entrepreneur effort and progress of project. In each round the information produced reduces information asymmetry. To account for this we control in which round the investment is. Since round number is not normally distributed we use natural logarithm of round number (Round Number). We also control for supply of CVC venture capital in focal year as share of total amount of investments in investment round that there are at least one CVC to total VC investments (share CVC deal Flow). In order to also take into account competition with independent VCs and entrepreneurial activities we control number of active independent VC relative to number of startups in focal year (IVC per Venture). The quality of startup is an important factor in decision of investors whether to invest or not (Kaplan and Stromberg, 2004). Following Dushnitsky and Shaver (2009), In order to consider the quality of the startup, we use a dummy variable (Successful exit) equal to one if startup had an exit through initial public offering or merger \& acquisition. We also control for number of investors in each round of investment (Syndication size). We control for geographic location of startups by two dummy variables for California and Massachusetts, which indicate whether ventures are located in the respective states. "Other States" is the omitted category. Several studies have shown that general market affect the investment decision of VCs (Nahata, 2008). VCs specially considers stock market since is the most important exit option. Hence we control for return of NASDAQ in focal year. The stage of development of entrepreneurial venture also affects the importance of technological secrecy and information asymmetry. We control for stage of development of entrepreneurial venture with five dummies whether venture is "Seed", "Early stage", "Late Stage", "Expansion" or "Other" (Omitted category). We use the classification reported by SDC Platinum. We also include year and industry fixed effect. $\underline{\text { Table } 1}$ reports variable definitions. 


\section{Analysis}

We use difference-in-difference methodology by exploiting the adoption of American Inventor's Protection act (AIPA) in 1999. Prior to AIPA the content of patents where only revealed when patent was granted, but after 1999, content of patents were disclosed within 18 months after filing date. We exploit the different affect that AIPA had on different industries and argue that industries with industries where the link between patents and rent generation is transparent were the ones affected by AIPA.

The empirical strategy allows us to investigate the interplay between startups' technological information revealing and our dependent variables, by looking at an exogenous shock of AIPA. We suggest that an increase in publicly available information about a startup's innovation reduces informational withholding and increases the likelihood and quality of match between CVC and startups. In all models $(i)$ is referring to startup, $(j)$ is representing round of investment and ( $\mathrm{t}$ ) represents time.

$y_{i j}=\beta_{1}+\beta_{2}$ Post $_{t}+\beta_{3}$ Treatment $_{i}+\beta_{4}$ Treatment $\times$ Post $_{t}+\beta_{5} \mathrm{Z}_{\mathrm{ijt}}+Y_{t}+\varepsilon_{i j t}$,

Where yit is the likelihood of receiving investment from CVC (Deal CVC) or amount of investment (Round Size). Post $t$ is a dummy variable indicating that investment is happened after enactment of AIPA or before that (Post-AIPA). Treatment ${ }_{i}$ is a dummy variable whether the startup operates in industries where the link between patents and innovative products is transparent or not (Transparent). The coefficient of interest is $\beta 4$, which varies at the $i t$ level.

$\mathrm{Z}_{\mathrm{ijt}}$ is a vector of control variables mentioned in the previous section. $Y_{t}$ denotes year fixed effects, and standard errors are clustered at the startup level. In the first set of analysis since our dependent variable (Deal $C V C$ ) is a dummy variable we use Logit regression. In the second set of analysis in which our dependent variable is continuous we use OLS regression. $\underline{\text { Table } 2}$ reports descriptive statistics and correlation of variables. 


\section{RESULTS}

\section{Likelihood match between CVC and startup}

In this section we investigate whether increase in technological information revealing affects the likelihood of receiving CVC investment. Table 3 reports Logit regression in difference-in-difference model.

\section{[Table 3 about here]}

In model 1 we use all investments. Model 2 reports results using alternative measure of transparent industries (Transparent1). In Model 3 we only consider two industries of "Biotechnology" and "Computer software". Model 4 and 5 report results, on subsample in which information asymmetry is much higher, respectively first round of investment and investment in "Seed" and "Early stage". The results in all models support our theoretical prediction $(\mathrm{H} 1)$ in which exogenous shock in revealing technological information increases likelihood of CVC-startup match. The coefficient of interaction between Post-AIPA and Transparent industry is significant at $99 \%$ level.

Apart from analysis reported model 3 we have done additional robustness checks. First, the AIPA coincide with internet bubble and crash of market afterward. In order to assure our results are not due to internet bubble we have controlled for several variables which can take into consideration internet bubble (competition between CVC and IVC, entrepreneurial activities and NASDAQ return). We also repeated our analysis (Table 4 ) by excluding year 2000 (Model 1), 2000 and 1999 (model 2), and 2000, 1999 and 2001 (Model3). The results support hypothesis one. 


\section{[Table 4 about here]}

Finally we conduct a placebo test to ensure that our findings is actually driven by the AIPA shock and is consistent with theoretical argument about information revealing. If our results are driven by the theoretical arguments, we expect that a fake tentative definition of shock not to generate similar results. As a placebo test, we define a fake alternative shock measure (Post-AIPA fake) in which gains the value one for years after 1997 and zero for before that. Our placebo test (Table 5) shows that alternative measure (Post-AIPA fake) does not generate significant results as our genuine variable (Post-AIPA), confirming the theoretical arguments ${ }^{3}$.

\section{[Table 5 about here]}

\section{Quality of match between CVC and startup}

In this section we study whether increasing technological information revealing increase the size of investments, which is a quality measure in our case. According to hypothesis 2 we expect that after the shock, size of investment increases for CVC backed startups (H2), while we do not expect such an effect independent VC backed startups. This is because VCs were not subject to strategic information withhold by startups, so the shock should not have an impact on their matching.

Table 6 shows that informational revealing increase size of investment for deals including at least one CVC (Model 1, 2, and 3). However we do not observe such a finding for deals including only independent VCs (Model 4, 5, and 6). Model 1 and 4 reports result of full sample. In model 2 and 5 we exclude rounds of investment in year 2000. Similarly in

\footnotetext{
${ }^{3}$ Although the majority of high-tech startups happen around a patent, there is a concern that some of the startups in our subsample may not own or apply for patents, and thus the AIPA would not affect them. To address this concern we have run our analyses over a subsample of startups matched with the available patent information. Our results remain robust in this subsample. The analyses are available upon request.
} 
model 3 and 6 we exclude rounds of investment in years 2000 and $1999^{4}$. The results are very similar across all models in case of size and significant level.

\section{[Table 6 about here]}

\section{Timing of match between CVC and startup}

Finally Table 7 shows the effect of information revealing on timing of the match. Models 1, 2, and 3 estimate a logistics regression while model 4 includes cox hazard model. In the first three columns, the dependent variable, Deal CVC, takes value one when a deal happens. The timing of the deal in these models is captured by the variable "Stage no". The causal impact of information disclosure in the first three columns is measured by the three way interaction between Post-AIPA, Transparent and Stage no. The negative coefficient reveals that post-AIPA, the CVC deals in transparent industries happen significantly faster (in earlier stage of development) compared to pre-AIPA period. Model 1 include full sample while in model 2, and 3 we exclude respectively year 2000, and $1999 \& 2000$. However, the results are very robust to this check.

Moreover, model 4 includes cox hazard model which estimates the time to hazard - CVC matching in this case. The model includes full sample. The estimated positive and significant coefficient (hazard ratio about one) implies that AIPA in transparent industries has increased the hazard rate and match happens faster. The results of table 7 in sum, confirms our theoretical arguments in hypothesis 3 on the effect of information exposure on timing of the match.

\section{[Table 7 about here]}

\footnotetext{
${ }^{4}$ In an unreported analysis we also repeated our analysis by excluding years $1999,2000, \& 2001$. Results are very similar to reported ones. We have not reported these results in the interest of space, however, they are available upon request.
} 


\section{CONCLUSION AND FUTURE DIRECTION}

Although corporate venture capitals are believed to have higher potentials for financing and nurturing new startups, the misappropriation concerns from the startups' side have generated serious information constraints for corporate investors. This have created adverse effects on the efficiency of CVC investments in high technology startups. Although there are definitely risks involved by corporate investments for startups, the bright side of such collaboration should also be taken in to account. Disclosing to a corporate investor, may give the startups the access to high complementary resources -including commercial, technological and human - which without them, the venture would not succeed or have a poor performance. Of course, this does not imply that CVCs do not have misappropriation objectives, but suggests that any analysis on the topic should also take the positive impacts into account. An important obstacle for such an analysis is measuring the causal effect information asymmetry on the investment matches. Our study investigates the causal impact of information revealing on the likelihood and quality of CVC-startup matches and confirms that strategic information withhold by startups have reduced the efficiency of CVC investments, while informational revealing increases the likelihood and quality of CVC-startup matching. These results still cannot conclude that a startup would be better off by revealing information to - and collaborating with- a CVC compared to an independent VC. However, as a first step, it provides unbiased evidence on the positive outcomes associated with such an action.

Analysis of the performance of CVC backed startups, as a result of information revealing stays as our next step in this project.

\section{REFRENCES}

Ahuja, G., 2000. Collaboration networks, structural holes, and innovation: A longitudinal study. Administrative science quarterly, 45(3), pp.425-455.

Alter, M., L. Buchsbaum. 2000. Corporate venturing: Goals, compensation, and taxes. D. Barry, ed. The Corporate Venturing Directory and Yearbook. Asset Alternatives, Wellesley, MA, 25-29. 
Alvarez-Garrido, E., \& Dushnitsky, G. 2015. Are entrepreneurial venture's innovation rates sensitive to investor complementary assets? Comparing biotech ventures backed by corporate and independent VCs. Strategic Management Journal: n/a-n/a.

Anton, J.J. and D.A. Yao. 1994. "Expropriation and Inventions: Appropriable Rents in the Absence of Property Rights.” American Economic Review. 84 190-209.

Aoki, R. and Spiegel, Y., 1998. Public Disclosure of Patent Applications, R\&D, and Welfare

Arora, A. and Ceccagnoli, M., 2006. Patent protection, complementary assets, and firms' incentives for technology licensing. Management Science,52(2), pp.293-308.

Arora, A., Fosfuri, A. and Gambardella, A., 2004. Markets for technology: The economics of innovation and corporate strategy. MIT press.

Arrow, K.J. 1962. "Economic Welfare and the Allocation of Resources for Inventions." In R. Nelson (ed.), The Rate and Direction of Inventive Activity: Economic and Social Factors. Princeton, N.J.: Princeton University Press.

Baum, J.A. and Silverman, B.S., 2004. Picking winners or building them? Alliance, intellectual, and human capital as selection criteria in venture financing and performance of biotechnology startups. Journal of business venturing, 19(3), pp.411436.

Benson, D., \& Ziedonis, R. H. 2009. Corporate Venture Capital as a Window on New Technologies: Implications for the Performance of Corporate Investors When Acquiring Startups. Organization Science, 20(2): 329-351.

Chemmanur, T. J., Loutskina, E., \& Tian, X. 2014. Corporate Venture Capital, Value Creation, and Innovation. Review of Financial Studies, 27(8): 2434-2473.

Cohen, W.M., Nelson, R.R. and Walsh, J.P., 2000. Protecting their intellectual assets: Appropriability conditions and why US manufacturing firms patent (or not) (No. w7552). National Bureau of Economic Research.

Cumming, D.J., 2006. The determinants of venture capital portfolio size: empirical evidence. Journal of Business, 79, pp.1083-1126.

Cumming, D., \& Dai, N. 2012. Why Do Entrepreneurs Switch Lead Venture Capitalists? Entrepreneurship Theory and Practice.

Dushnitsky, G., \& Lenox, M. J. 2005a. When do firms undertake R\&D by investing in new ventures? Strategic Management Journal, 26(10): 947-965.

Dushnitsky, G., \& Lenox, M. J. 2005b. When do incumbents learn from entrepreneurial ventures? Corporate venture capital and investing firm innovation rates. Research Policy, 34(5): 615-639.

Dushnitsky, G., \& Lenox, M. J. 2006. When does corporate venture capital investment create firm value? Journal of Business Venturing, 21(6): 753-772.

Dushnitsky, G., \& Shaver, J. M. 2009. Limitations to Interorganizational Knowledge Acquisition: the Paradox of Corporate Venture Capital. Strategic Management Journal, 30(10): 1045-1064.

Gallini, N.T., 2002. The economics of patents: Lessons from recent US patent reform. Journal of Economic Perspectives, pp.131-154.

Gans, J.S., Hsu D., \& Stern. S. "The impact of uncertain intellectual property rights on the market for ideas: Evidence from patent grant delays." Management Science 54.5 (2008): 982-997.

Gans, J.S. and Stern, S., 2003. The product market and the market for "ideas":

commercialization strategies for technology entrepreneurs. Research policy, 32(2), pp.333350 . 
Gompers, P. A. 1995. Optimal investment, monitoring, and the staging of venture capital. The journal of finance, 50(5): 1461-1489.

Gompers, P. A., \& Lerner, J. 2004. The Venture Capital Cycle. Cambridge and London: MIT Press.

Graham, S., \& Hegde, D. 2015. Disclosing patents' secrets. Science, 347(6219): 236-237.

Gulati, R. and Singh, H., 1998. The architecture of cooperation: Managing coordination costs and appropriation concerns in strategic alliances.Administrative science quarterly, pp.781-814.

Heeley, M. B., Matusik, S. F., \& Jain, N. 2007. Innovation, appropriability, and the underpricing of initial public offerings. Academy of Management Journal, 50(1): 209-225.

Hellmann, T., \& Puri, M. 2002. Venture capital and the professionalization of start-up firms: Empirical evidence. Journal of Finance, 57(1): 169-197.

Hsu, D. H. 2006. Venture Capitalists and Cooperative Start-up Commercialization Strategy. Management Science, 52(2): 204-219.

Hsu, D.H. and Ziedonis, R.H., 2013. Resources as dual sources of advantage: Implications for valuing entrepreneurial-firm patents. Strategic Management Journal, 34(7), pp.761781.

Kaplan, S. N., \& Stromberg, P. 2004. Characteristics, contracts, and actions: Evidence from venture capitalist analyses. Journal of Finance, 59(5): 2177-2210.

Katila, R. and Mang, P.Y., 2003. Exploiting technological opportunities: the timing of collaborations. Research policy, 32(2), pp.317-332.

Katila, R., Rosenberger, J. D., \& Eisenhardt, K. M. 2008. Swimming with sharks: Technology ventures, defense mechanisms and corporate relationships. Administrative Science Quarterly, 53(2): 295-332.

Kortum, S., \& Lerner, J. 2000. Assessing the contribution of venture capital to innovation. Rand Journal of Economics, 31(4): 674-692.

Mann, R.J. and Sager, T.W., 2007. Patents, venture capital, and software start-ups. Research Policy, 36(2), pp.193-208.

Maula, M. and Murray, G., 2002. Corporate venture capital and the creation of US public companies: The impact of sources of venture capital on the performance of portfolio companies. Creating value: Winners in the new business environment, pp.164-187.

Nahata, R. 2008. Venture capital reputation and investment performance. Journal of Financial Economics, 90(2): 127-151.

Sahlman, W. A. 1990. The Structure and Governance of Venture-Capital Organizations. Journal of Financial Economics, 27(2): 473-521.

Siegel, R., Siegel, E. and MacMillan, I.C., 1988. Corporate venture capitalists: Autonomy, obstacles, and performance. Journal of Business Venturing, 3(3), pp.233-247.

Ueda, M., 2004. Banks versus venture capital: Project evaluation, screening, and expropriation. The Journal of Finance, 59(2), pp.601-621.

Yost, M., K. Devlin. 1993. The state of corporate venturing. Venture Capital J. 37-40 
Table 1- Variable Definitions

\begin{tabular}{|c|c|}
\hline Variables & Definitions \\
\hline Deal CVC & A dummy indicating at least one of investors in round of investment is CVC. \\
\hline Round size $(\ln )$ & Natural Logarithm of amount investment (inflated by millions of 2007 dollar). \\
\hline Stage no. & $\begin{array}{l}\text { A count variable which varies between } 1 \text { and } 5 \text {. It receive value one for seed } \\
\text { stage and increases with development of venture. }\end{array}$ \\
\hline Post-AIPA & Dummy variable indicating that round of investment is after year 2000 . \\
\hline Transparent & $\begin{array}{l}\text { Dummy variable indication that venture industry is Biotechnology and } \\
\text { Medical/Health/Life Science. }\end{array}$ \\
\hline Transparent1 & $\begin{array}{l}\text { Dummy variable indication that venture industry is in Biotechnology, } \\
\text { Medical/Health/Life Science and Semiconductors/Other Elect. }\end{array}$ \\
\hline $\begin{array}{l}\text { Round number } \\
(\ln )\end{array}$ & Natural Logarithm of number of round of investment. \\
\hline $\begin{array}{l}\text { Share CVC deal } \\
\text { flow }\end{array}$ & Share of CVC investment relative to total investments. \\
\hline $\begin{array}{l}\text { IVC per } \\
\text { Venture }\end{array}$ & Number independent VC relative to entrepreneurial ventures. \\
\hline Successful exit & Dummy: it equals 1 if entrepreneurial venture had IPO or M\&A. \\
\hline Syndication size & $\begin{array}{l}\text { Number of investors that co-invested in the same deal in entrepreneurial } \\
\text { venture. }\end{array}$ \\
\hline California & $\begin{array}{l}\text { Dummy variable indicating that entrepreneurial venture is located in } \\
\text { California. }\end{array}$ \\
\hline Massachusetts & $\begin{array}{l}\text { Dummy variable indicating that entrepreneurial venture is located in } \\
\text { Massachusetts. }\end{array}$ \\
\hline Nasdaq & The return of NASDAQ stock market. \\
\hline $\begin{array}{l}\text { Industry fixed } \\
\text { effect }\end{array}$ & $\begin{array}{l}5 \text { dummies whether industry is Biotechnology, Communications and Media, } \\
\text { Computer Related, Medical/Health/Life Science, Semiconductors/Other Elect. }\end{array}$ \\
\hline $\begin{array}{l}\text { Stage fixed } \\
\text { effect }\end{array}$ & $\begin{array}{l}5 \text { dummies whether entrepreneurial venture is in "Seed", "Early stage", "Late } \\
\text { stage", "Expansion" or "Other stages". }\end{array}$ \\
\hline
\end{tabular}


Table 2- Descriptive statistics and correlation matrix

\begin{tabular}{lrrrrrrrrrrrrr}
\hline & Mean & S.D. & \multicolumn{1}{c}{ Min } & \multicolumn{1}{c}{ Max } & (1) & (2) & (3) & (4) & (5) & (6) & (7) & (8) & (9) \\
\hline 1-Deal CVC & 0.204 & 0.403 & 0 & 1 & & & & & & & & & \\
2-Round size (ln) & 8.247 & 1.518 & 0 & 13.71 & 0.28 & 1 & & & & & & & \\
3-Round number (ln) & 0.844 & 0.69 & 0 & 5.069 & 0.09 & 0.01 & 1 & & & & & & \\
4-Share CVC deal flow & 0.277 & 0.089 & 0.107 & 0.406 & 0.13 & 0.25 & -0.07 & 1 & & & & & \\
5-IVC per Venture & 0.298 & 0.073 & 0.22 & 0.406 & -0.02 & -0.01 & 0.18 & -0.21 & 1 & & & & \\
6-Successful exit & 0.33 & 0.47 & 0 & 1 & 0.02 & 0.06 & 0.06 & -0.08 & -0.2 & 1 & & & \\
7-Syndication size & 3.275 & 2.518 & 1 & 33 & 0.39 & 0.5 & 0.23 & 0.11 & 0.03 & 0.04 & 1 & & \\
8-California & 0.397 & 0.489 & 0 & 1 & 0.05 & 0.1 & 0.02 & -0.02 & 0.00 & 0.03 & 0.08 & 1 & \\
9-Massachusetts & 0.118 & 0.322 & 0 & 1 & -0.01 & 0.01 & 0.03 & -0.02 & 0.03 & 0.02 & 0.04 & -0.3 & 1 \\
10-Nasdaq & 0.109 & 0.396 & -0.393 & 0.856 & -0.05 & -0.1 & 0.00 & -0.33 & -0.15 & 0.09 & -0.05 & 0.03 & 0.01 \\
\hline
\end{tabular}


Table 3- Impact of informational revealing on likelihood of receiving investment from CVC

\begin{tabular}{|c|c|c|c|c|c|}
\hline & $\begin{array}{c}\text { (1) } \\
\text { Deal CVC }\end{array}$ & $\begin{array}{c}(2) \\
\text { Deal CVC } \\
\end{array}$ & $\begin{array}{c}\text { (3) } \\
\text { Deal CVC }\end{array}$ & $\begin{array}{c}\text { (4) } \\
\text { Deal CVC } \\
\end{array}$ & $\begin{array}{c}\text { (5) } \\
\text { Deal CVC }\end{array}$ \\
\hline Post-AIPA & $\begin{array}{l}0.837^{\text {*** }} \\
(0.181)\end{array}$ & $\begin{array}{l}0.785^{\text {*** }} \\
(0.182)\end{array}$ & $\begin{array}{l}0.772^{* *} \\
(0.304)\end{array}$ & $\begin{array}{l}1.105^{\text {*** }} \\
(0.383)\end{array}$ & $\begin{array}{l}0.852^{* *} \\
(0.360)\end{array}$ \\
\hline Transparent & $\begin{array}{l}-0.737^{\text {*** }} \\
(0.108)\end{array}$ & & $\begin{array}{l}-0.073 \\
(0.143)\end{array}$ & $\begin{array}{l}-0.725^{\text {**** }} \\
(0.163)\end{array}$ & $\begin{array}{l}-0.565^{\text {*** }} \\
(0.154)\end{array}$ \\
\hline Post-AIPA * Transparent & $\begin{array}{l}0.498^{* * *} \\
(0.100)\end{array}$ & & $\begin{array}{l}0.434^{* * *} \\
(0.162)\end{array}$ & $\begin{array}{l}0.580^{* * * *} \\
(0.163)\end{array}$ & $\begin{array}{l}0.633^{* * *} \\
(0.156)\end{array}$ \\
\hline Transparent 1 & & $\begin{array}{l}-0.110 \\
(0.083)\end{array}$ & & & \\
\hline Post-AIPA ${ }^{*}$ Transparent 1 & & $\begin{array}{l}0.523^{* * *} \\
(0.083)\end{array}$ & & & \\
\hline Round number (ln) & $\begin{array}{l}-0.026 \\
(0.032)\end{array}$ & $\begin{array}{l}-0.024 \\
(0.032)\end{array}$ & $\begin{array}{l}-0.004 \\
(0.055)\end{array}$ & & $\begin{array}{l}-0.060 \\
(0.053)\end{array}$ \\
\hline share CVC deal flow & $\begin{array}{c}1.168 \\
(2.199)\end{array}$ & $\begin{array}{c}1.105 \\
(2.204)\end{array}$ & $\begin{array}{c}2.484 \\
(3.640)\end{array}$ & $\begin{array}{l}-0.035 \\
(5.589)\end{array}$ & $\begin{array}{c}1.796 \\
(4.977)\end{array}$ \\
\hline IVC per Venture & $\begin{array}{l}-7.263^{* *} \\
(3.064)\end{array}$ & $\begin{array}{l}-7.380^{* *} \\
(3.072)\end{array}$ & $\begin{array}{l}-6.139 \\
(5.028)\end{array}$ & $\begin{array}{l}-11.357 \\
(7.576)\end{array}$ & $\begin{array}{l}-6.850 \\
(6.893)\end{array}$ \\
\hline Successful exit & $\begin{array}{c}0.070^{*} \\
(0.043)\end{array}$ & $\begin{array}{c}0.074^{*} \\
(0.043)\end{array}$ & $\begin{array}{c}0.045 \\
(0.073)\end{array}$ & $\begin{array}{c}0.085 \\
(0.064)\end{array}$ & $\begin{array}{c}0.048 \\
(0.065)\end{array}$ \\
\hline Syndication size & $\begin{array}{l}0.334^{* * *} \\
(0.008)\end{array}$ & $\begin{array}{l}0.334^{* * *} \\
(0.008)\end{array}$ & $\begin{array}{l}0.326^{* * *} \\
(0.014)\end{array}$ & $\begin{array}{l}0.391^{* * *} \\
(0.017)\end{array}$ & $\begin{array}{l}0.380^{* * *} \\
(0.017)\end{array}$ \\
\hline California & $\begin{array}{l}0.145^{* * *} \\
(0.041)\end{array}$ & $\begin{array}{l}0.145^{* * *} \\
(0.041)\end{array}$ & $\begin{array}{c}0.137^{*} \\
(0.072)\end{array}$ & $\begin{array}{l}0.128^{* *} \\
(0.059)\end{array}$ & $\begin{array}{c}0.088 \\
(0.061)\end{array}$ \\
\hline Massachusetts & $\begin{array}{l}-0.087 \\
(0.066)\end{array}$ & $\begin{array}{l}-0.088 \\
(0.066)\end{array}$ & $\begin{array}{l}-0.101 \\
(0.104)\end{array}$ & $\begin{array}{l}-0.070 \\
(0.099)\end{array}$ & $\begin{array}{l}-0.091 \\
(0.096)\end{array}$ \\
\hline Nasdaq & $\begin{array}{l}-0.174 \\
(0.234)\end{array}$ & $\begin{array}{l}-0.163 \\
(0.235)\end{array}$ & $\begin{array}{l}-0.250 \\
(0.385)\end{array}$ & $\begin{array}{c}0.121 \\
(0.595)\end{array}$ & $\begin{array}{l}-0.052 \\
(0.506)\end{array}$ \\
\hline Year fixed effect & Yes & Yes & Yes & Yes & Yes \\
\hline Industry fixed effect & Yes & Yes & Yes & Yes & Yes \\
\hline Stage fixed effect & Yes & Yes & Yes & Yes & Yes \\
\hline Constant & $\begin{array}{l}-1.365 \\
(1.641) \\
\end{array}$ & $\begin{array}{l}-1.500 \\
(1.644) \\
\end{array}$ & $\begin{array}{l}-2.304 \\
(2.698) \\
\end{array}$ & $\begin{array}{l}-0.061 \\
(4.143) \\
\end{array}$ & $\begin{array}{l}-1.927 \\
(3.716) \\
\end{array}$ \\
\hline $\mathrm{N}$ & 38,286 & 38,286 & 13,706 & 11,779 & 14,052 \\
\hline No. ventures & 14,418 & 14,418 & 4,958 & 11,779 & 9,654 \\
\hline Chi-square(p-value) & 0.000 & 0.000 & 0.000 & 0.000 & 0.000 \\
\hline
\end{tabular}

Note: In all models clustered Robust Std. Err. is reported in parentheses; $*$,** or *** indicate statistical significance at the $10 \%, 5 \%, 1 \%$ level, respectively. 
Table 4- Robustness check by excluding internet bubble years (2000, 1999, and 2001)

\begin{tabular}{|c|c|c|c|}
\hline & (1) & $\begin{array}{c}(2) \\
\text { Deal CVC }\end{array}$ & (3) \\
\hline Post-AIPA & $\begin{array}{c}0.741^{*} \\
(0.404)\end{array}$ & $\begin{array}{c}1.095^{*} \\
(0.613)\end{array}$ & $\begin{array}{c}1.052^{*} \\
(0.617)\end{array}$ \\
\hline Transparent & $\begin{array}{l}-0.635^{\text {*** }} \\
(0.120)\end{array}$ & $\begin{array}{l}-0.558^{* * *} \\
(0.133)\end{array}$ & $\begin{array}{l}-0.564^{* * *} \\
(0.135)\end{array}$ \\
\hline Post-AIPA ${ }^{*}$ Transparent & $\begin{array}{l}0.357^{* * *} \\
(0.112)\end{array}$ & $\begin{array}{l}0.269^{* *} \\
(0.125)\end{array}$ & $\begin{array}{l}0.373^{\text {*** }} \\
(0.131)\end{array}$ \\
\hline Round number (ln) & $\begin{array}{c}0.057 \\
(0.035)\end{array}$ & $\begin{array}{c}0.033 \\
(0.039)\end{array}$ & $\begin{array}{c}0.039 \\
(0.041)\end{array}$ \\
\hline share CVC deal flow & $\begin{array}{c}0.821 \\
(2.193)\end{array}$ & $\begin{array}{c}0.838 \\
(2.190)\end{array}$ & $\begin{array}{c}0.900 \\
(2.201)\end{array}$ \\
\hline IVC per Venture & $\begin{array}{l}-7.604^{* *} \\
(3.059)\end{array}$ & $\begin{array}{l}-7.584^{* *} \\
(3.057)\end{array}$ & $\begin{array}{l}-7.523^{* *} \\
(3.075)\end{array}$ \\
\hline Successful exit & $\begin{array}{c}0.033 \\
(0.048)\end{array}$ & $\begin{array}{c}0.038 \\
(0.053)\end{array}$ & $\begin{array}{c}0.026 \\
(0.059)\end{array}$ \\
\hline Syndication size & $\begin{array}{l}0.274^{\text {*** }} \\
(0.009)\end{array}$ & $\begin{array}{l}0.278^{* * *} \\
(0.010)\end{array}$ & $\begin{array}{l}0.286^{* * *} \\
(0.011)\end{array}$ \\
\hline California & $\begin{array}{c}0.077^{*} \\
(0.045)\end{array}$ & $\begin{array}{l}0.113^{* *} \\
(0.049)\end{array}$ & $\begin{array}{c}0.114^{* *} \\
(0.054)\end{array}$ \\
\hline Massachusetts & $\begin{array}{l}-0.123^{*} \\
(0.072)\end{array}$ & $\begin{array}{l}-0.059 \\
(0.077)\end{array}$ & $\begin{array}{l}-0.018 \\
(0.083)\end{array}$ \\
\hline Nasdaq & $\begin{array}{l}-0.142 \\
(0.233)\end{array}$ & $\begin{array}{l}-0.140 \\
(0.233)\end{array}$ & $\begin{array}{l}-0.142 \\
(0.234)\end{array}$ \\
\hline Year fixed effect & Yes & Yes & Yes \\
\hline Industry fixed effect & Yes & Yes & Yes \\
\hline Stage fixed effect & Yes & Yes & Yes \\
\hline Constant & $\begin{array}{l}-2.601^{* *} \\
(1.307) \\
\end{array}$ & $\begin{array}{l}-2.820^{* * *} \\
(1.059)\end{array}$ & $\begin{array}{l}-2.713^{* *} \\
(1.068) \\
\end{array}$ \\
\hline $\mathrm{N}$ & 31,516 & 26,952 & 22,991 \\
\hline No. ventures & 12,839 & 11,612 & 10,364 \\
\hline Chi-square(p-value) & 0.000 & 0.000 & 0.000 \\
\hline
\end{tabular}

Note: In all models clustered Robust Std. Err. is reported in parentheses; $*, * *$ or $* * *$ indicate statistical significance at the $10 \%, 5 \%, 1 \%$ level, respectively. 
Table 5- Placebo Test

(1)

Deal CVC

\begin{tabular}{lc}
\hline Post-AIPA fake & $1.105^{*}$ \\
& $(0.613)$ \\
Transparent & $-0.443^{* * *}$ \\
& $(0.147)$ \\
Post-AIPA fake ${ }^{*}$ Transparent & 0.037 \\
& $(0.136)$ \\
Round number (ln) & 0.038 \\
& $(0.032)$ \\
Share of CVC deal flow & 0.747 \\
& $(2.196)$ \\
IVC per Venture & $-7.746^{* *}$ \\
& $(3.062)$ \\
Successful exit & 0.031 \\
& $(0.043)$ \\
Syndication size & $0.276^{* * *}$ \\
& $(0.009)$ \\
California & $0.097^{* * *}$ \\
& $(0.041)$ \\
Massachusetts & -0.103 \\
& $(0.066)$ \\
Nasdaq & -0.128 \\
& $(0.234)$ \\
Year fixed effect & Yes \\
Industry fixed effect & Yes \\
Stage fixed effect & Yes \\
Constant & $-3.149^{* * *}$ \\
& $(1.056)$ \\
\hline N & 38,286 \\
No. ventures & 14,418 \\
Chi-square(p-value) & 0.000 \\
\hline Not In all & \\
&
\end{tabular}

Note: In all models clustered Robust Std. Err. is reported in parentheses; * ,** or $* * *$ indicate statistical significance at the $10 \%, 5 \%, 1 \%$ level, respectively. 
Table 6- Impact of informational revealing on size of investment.

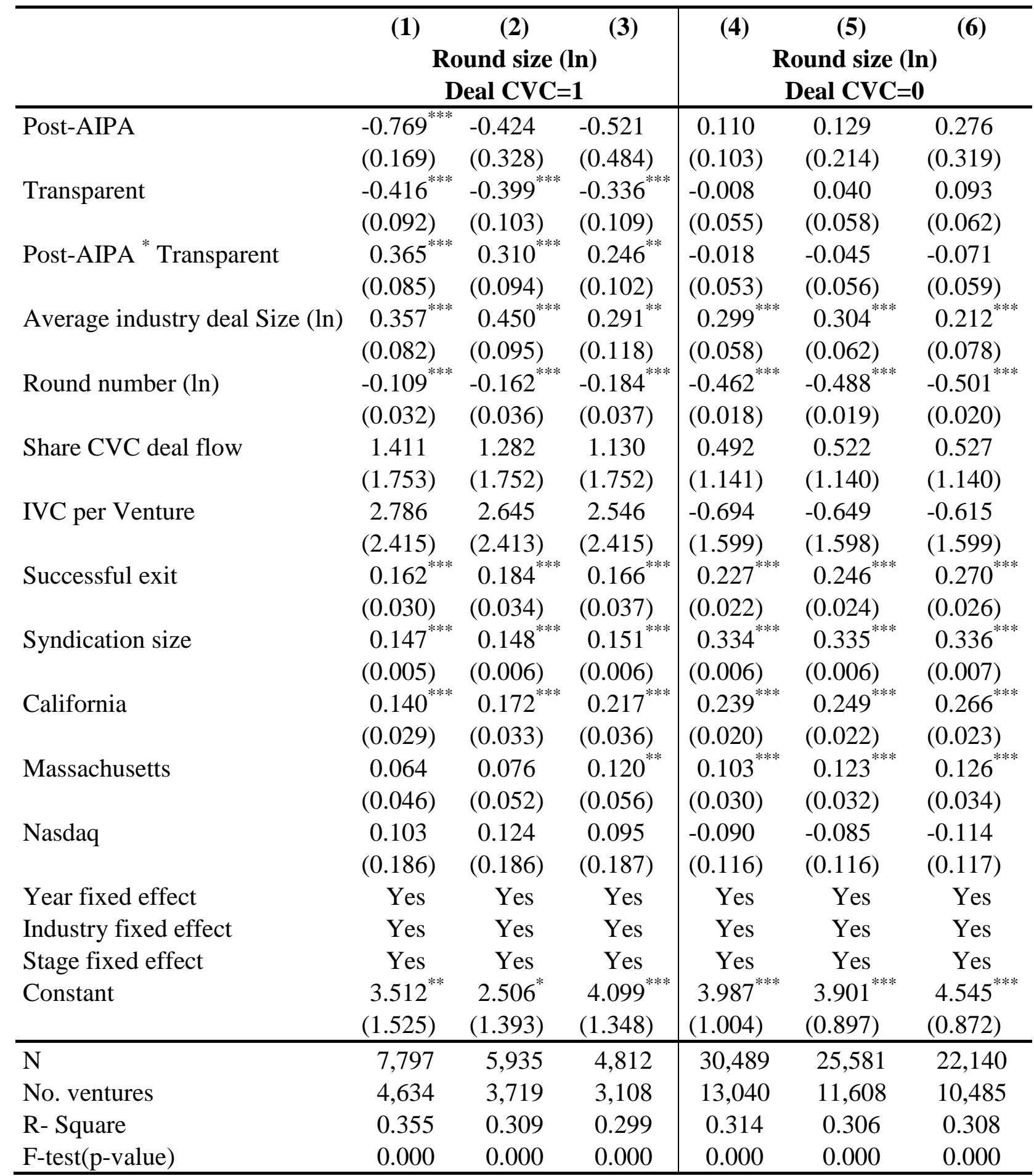

Note: In all models clustered Robust Std. Err. is reported in parentheses; $*$,** or *** indicate statistical significance at the $10 \%, 5 \%, 1 \%$ level, respectively. 
Table 7- Effect of information revealing on timing of match and hazard of match. Model 1, 2 , and 3 is logistics regression while model 4 includes cox hazard model. Model 1 and 4 include full sample while in model 2, and 3 we exclude respectively year 2000, and 1999 \& 2000.

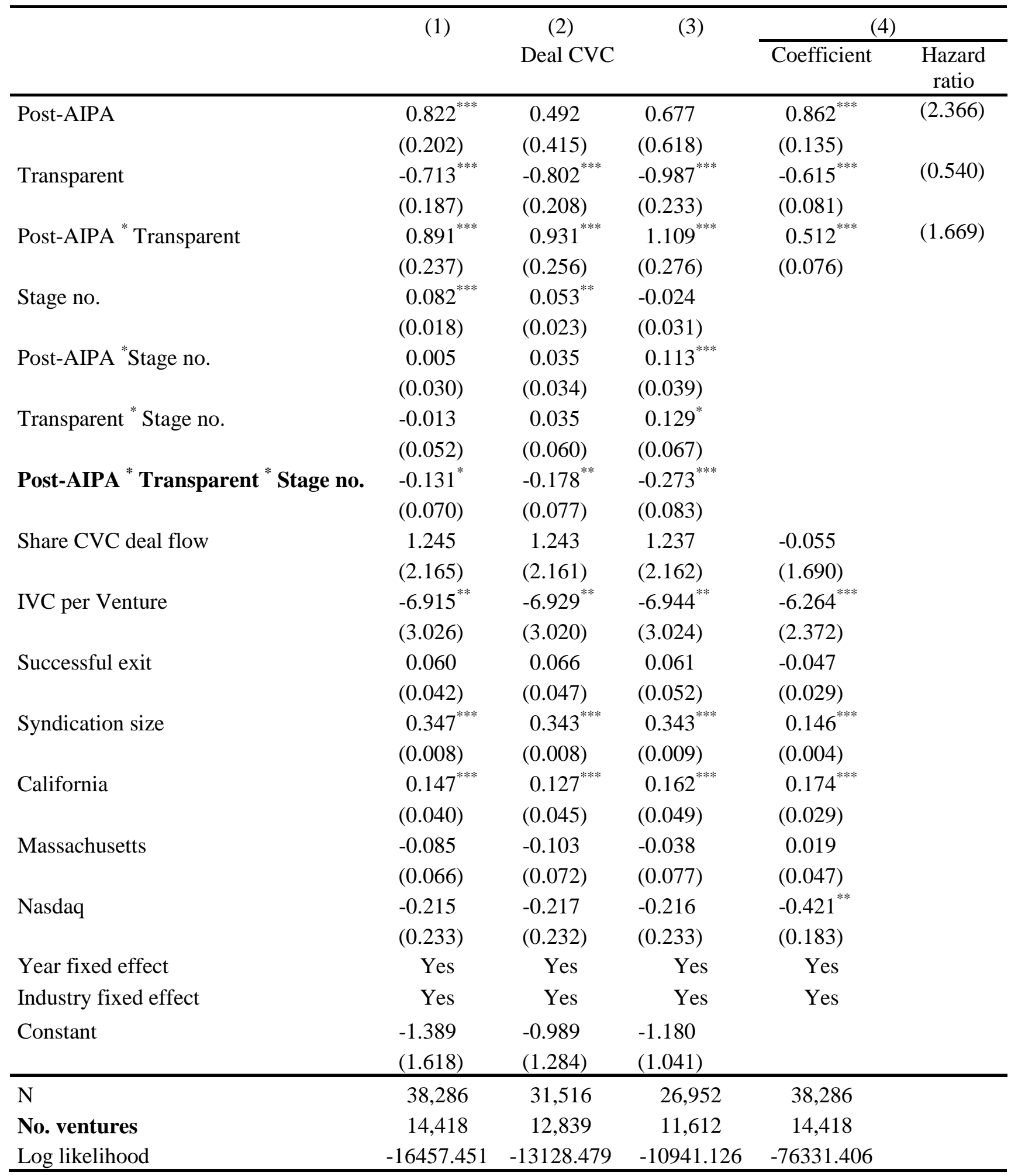


Note: In all models clustered Robust Std. Err. is reported in parentheses; *** or *** indicate statistical significance at the $10 \%, 5 \%, 1 \%$ level, respectively 